\title{
Key Determinants of Online Product Purchase Decisions for Students in Surabaya City (Case Study at FEB Students, Dr. Soetomo University)
}

\author{
Firdaus $^{1}$, Sukesi $^{2}$, Windyra Fitriani ${ }^{3}$, Meithiana Indrasari ${ }^{4}$, Sugiyanto ${ }^{5}$ \\ \{firdaus@unitomo.ac.id ${ }^{1}$, sukesi@unitomo.ac.id ${ }^{2}$, wiindy9@gmail.com ${ }^{3}$ \} \\ 1,2,3,4,5 Economics and Business Faculty, Dr Soetomo University, Indonesia
}

\begin{abstract}
Online buying and selling is popping up, competition is getting stronger and lighter, so online buying and selling companies are competent to attract the attention of consumers. Respondents in this study were FEB University Students Dr. Soetomo Surabaya with a sample of 92 respondents. Online, what are the dominant factors in FEB University students Dr.Soetomo Surabaya. And IBM SPSS version 21.00 analysis tool Functional Factors, Convenience Factors, Personal Factors that determine product purchasing decisions online at FEB University Students Dr. Soetomo Surabaya and Psychological and Social Factors are the dominant Factors.
\end{abstract}

Keywords: Psychological and social, functional, ease, personal, purchasing decision.

\section{Introduction}

At present the development of technology is very rapid and continues to evolve over time. Technology has become an important role in human life. Technological advancements provide changes in various fields, ranging from transportation, communication and business and marketing, which are now easier with the internet. Various information can be presented through face to face directly through sophisticated sophisticated telecommunications equipment. This makes many people use the technology to make buying and selling online transactions because it can provide convenience to the community, so that they can connect without problems.

This is clearly a very promising business potential. The development of internet users has been led to a great potential for the creation of online shopping. Therefore, the opportunity to run online business is increasingly open to business people in Indonesia. Online shop or online shopping activity has become a lifestyle for internet users. The online business itself has flourished in Indonesia in recent years. It can be said that in the last decade the development of online business in Indonesia is very rapid, its development covers various kinds of business fields. In Indonesia, there are many online buying and selling sites including Tokobagus, Kaskus, Tokopedia, Bukalapak, Lazada, olx and others. In other words, large internet users in Indonesia make Indonesia a potential market for online business facilities.

Consumers have several factors in making purchasing decisions behind the rise of online shopping among the Indonesian people, starting from price factors, psychological factors, functional factors, convenience factors, social factors, promotion factors and personal factors. Purchasing decisions according to Kotler and Keller [1] are the processes of purchasing decisions where consumers actually make the decision to buy. The process of purchasing decisions is divided into five stages, namely problem recognition, information search, evaluation of alternatives, purchasing decisions, and post-purchase behavior. In order for 
companies to attract competitive prices with similar companies, they must determine the decision to purchase products online and which factors are the main determinants of consumer purchasing decisions.

Online and analyze which factors are the main determinants of consumer purchasing decisions?

\section{Theoretical Framework}

According to Tjiptono [2] Marketing is a social and managerial process where individuals or groups need to do through creation, coloring, and exchange for everything that is of value with other people or groups. E-Commerce according to Suyanto [3] is the purchase, sale and marketing of goods and services through electronic systems. Like television, radio and computer networks or the internet. E-Commerce can also be interpreted as a process of doing business using electronic technology that connects companies, consumers and society in the form of electronic transactions.

According to Mowen, consumer behavior is an individual decides to buy, conduct an exchange process involving acquisition, consumption and disposal of goods, experience services. According to Kotler [4], to arrive at the purchase stage, there are steps in the purchasing process with a. stage. The decision making process includes stages: identification of needs, alternative searches, evaluation of alternatives, buying behavior, and buying behavior. Factors Affecting Purchasing Decisions Some of the factors that influence consumer behavior are as follows: Kotler [4] explains that now the internet also has a share in reversing the trend of fixed pricing. Price is an important factor that influences purchasing decisions. In some online categories, the prices are significantly lower than the price list for purchasing outlets, so they are important in influencing purchasing decisions on online stores. Price factor includes price competitiveness, price affordability.

Psychological factors are important factors that can overcome crises and difficulties between business partners. Besides, it is also important asset in developing long-term between organizations. An organization must be able to recognize the factors that can shape the psychological order to be able to create, organize, maintain, support and enhance the level of relationship with customers [5]. Psychological factors include the belief that the company has a good reputation, guarantees security and confidentiality. According to Contantinides [5] states functional factors or factors that enhance online experience by presenting good performance, responsiveness or rapid response and interactive network sites to customers. Functional factors include structuring neat and easily understood features, the information provided is complete and accurate, responding to buyers' requests are accurate and quickly, able to establish good relationships with buyers.

Kotler [4] defines convenience in online marketing, where customers can order products 24 hours a day wherever they are. Ease factors / technological advancements include the use of flexible, energy efficient, time efficiency. Social Factors [1] These are factors that arise from the consumer's social environment. social factors include reference groups and families. Promotion Factors [1]. Promotion is a marketing function that focuses on communicating persuasive to target customers or prospective customers to encourage the purchase decision. Promotional factors include advertisements, discounts / discounts.

Personal factors [1] Buyer behavior is also influenced by personal characteristics. These characteristics include lifestyle, needs, reuse, experience. 


\section{Hypothesis}

- Allegedly there are several factors that determine the decision to purchase products online at FEB University Students DR. Soetomo Surabaya.

- Allegedly most important psychological factors that determine the decision to purchase products online at FEB University Students, DR. Soetomo Surabaya.

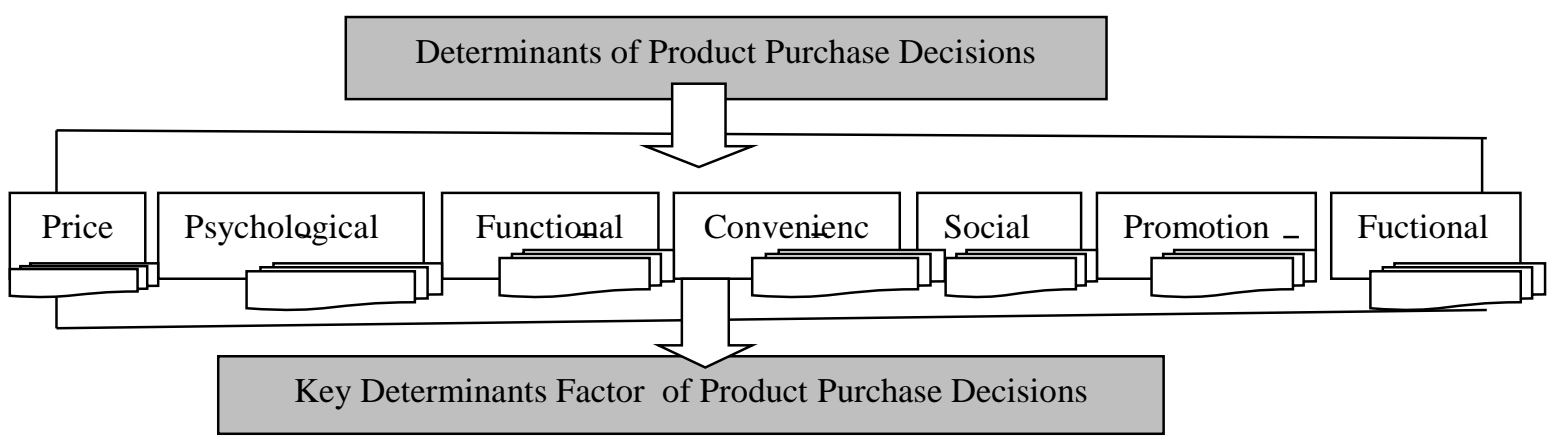

Fig. 1. Conceptual Framework

\section{Research Approach Methods}

This study uses a quantitative approach. According to Sugiyono [6], a quantitative approach is an approach in research that uses data in the form of numbers. This study is used to examine the population or a particular sample, using research instruments, with the aim of testing the hypothesis that it has been set.

\subsection{Population and Samples}

According to Sugiyono [6], the notion of population is a generalization region. The population study was all FEB students at the University of DR. Soetomo Surabaya with a total of 1226 students in 2018. Samples are part of the number and characteristics of the population [6]. Sampling in this study uses a proportional sampling technique using Slovin formula. According to Sugiyono [6] Proportional sampling is a sample calculated based on comparison. Because in the population there are several sub-populations or the existing population is not homogeneous. The sample that was used by respondents with purposive sampling was aside from certain criteria, namely FEB online who had purchased products. With management students totaling 55 people, accounting for 34 people and development economics of 3 people.

\subsection{Analysis Method}

Test validity, the test used to measure the validity or validity of a questionnaire. A questionnaire that is valid for the question in the questionnaire can reveal something that will be measured by the questionnaire [7]. Validation test is done by comparing the r-count value with the r-table value for the degree of freedom $\mathrm{d}(\mathrm{f})=\mathrm{n}-\mathrm{k}$ with alpha 0.05 .

Reliability test, tests results from time to time [7]. The reliability test uses a one shot method, which is measured by the Cronbach Alpha $(\alpha)$ statistical test. A construct or variable is the value of Cronbach Alpha $(\alpha)>0.60$ [7]. 
Factor Analysis, a technique used to look for factors that explain the relationship or correlation between various independent indicators observed. Factor analysis is extension of the main component analysis. It is also used to identify a number of relatively small factors that can be used to explain a large number of interconnected variables. The purpose of factor analysis is to describe the relationship between several underlying but observed variables, random quantities called factors [8].

\section{Research and Discussion}

Validity test according to Sarwono [7] is a condition that approaches the truth or error contained in inferences, propositions, and conclusions. The value of $r$ is calculated with the $r$ value of the table with deegree freedom $(\mathrm{df})=\mathrm{n}-2$ with alpha 0.05

Table 1. Validity Test

\begin{tabular}{|c|c|c|c|c|}
\hline Variable & Indicator & Corelation & Sig & Validity \\
\hline \multirow[t]{2}{*}{ Price (X.1) } & $\mathrm{X} 1.1$ & 0,906 & 0,000 & Valid \\
\hline & $\mathrm{X} 1.2$ & 0,887 & 0,000 & Valid \\
\hline \multirow[t]{2}{*}{ Psychological(X.2) } & $\mathrm{X} 2.1$ & 0,936 & 0,000 & Valid \\
\hline & $\mathrm{X} 2.2$ & 0,945 & 0,000 & Valid \\
\hline \multirow[t]{4}{*}{ Functional(X.3) } & X3.1 & 0,947 & 0,000 & Valid \\
\hline & X3.2 & 0,828 & 0,000 & Valid \\
\hline & X3.3 & 0,906 & 0,000 & Valid \\
\hline & X3.4 & 0,929 & 0,000 & Valid \\
\hline \multirow[t]{2}{*}{ Convenience (X.4) } & $\mathrm{X} 4.1$ & 0,812 & 0,000 & Valid \\
\hline & $\mathrm{X} 4.2$ & 0,778 & 0,000 & Valid \\
\hline \multirow[t]{2}{*}{ Social (X.5) } & X5.1 & 0,918 & 0,000 & Valid \\
\hline & X5.2 & 0,932 & 0,000 & Valid \\
\hline \multirow[t]{2}{*}{ Promotion (X.6) } & X6.1 & 0,888 & 0,000 & Valid \\
\hline & X6.2 & 0,905 & 0,000 & Valid \\
\hline \multirow[t]{4}{*}{ Personal (X.7) } & X7.1 & 0,616 & 0,000 & Valid \\
\hline & X7.2 & 0,631 & 0,000 & Valid \\
\hline & X7.3 & 0,792 & 0,000 & Valid \\
\hline & X7.4 & 0,692 & 0,000 & Valid \\
\hline
\end{tabular}

Source: Primary Data is Processed

From table 1 above shows that all the indicators used to have a correlation coefficient are greater than the table, for a sample of 92 respondents, namely 0.2050 . And counts $>0.05$ from these results indicate that all of these indicators are valid.

Reliability testing according to Sarwono [7] is a different time context. The reliability of the variable is determined based on the Cronbach alpha value, if the alpha value is greater than 0.6 then the variable is said to be reliable or reliable. 
Table 2. Reliability Test

\begin{tabular}{lcc}
\hline \multicolumn{1}{c}{ Variable } & Crobach Alpha & Reliability \\
\hline Price (X.1) & 0,755 & Reliabel \\
Psychological(X.2) & 0,869 & Reliabel \\
Functional(X.3) & 0,924 & Reliabel \\
Convenience (X.4) & 0,692 & Reliabel \\
Social (X.5) & 0,830 & Reliabel \\
Promotion (X.6) & 0,755 & Reliabel \\
Personal (X.7) & 0,624 & Reliabel \\
\hline Source: Primary Data is Processed &
\end{tabular}

Based on table 2 above, it shows that there is a large enough Alpha coefficient which is above 0.60 so that it is a reliable questionnaire.

Table 3. KMO and Barlett's Test

\begin{tabular}{llr}
\hline Kaiser-Meyer-Olkin Measure of Sampling Adequacy. & .829 \\
& Approx. Chi-Square & 1041.240 \\
Bartlett's Test of Sphericity & Df & 105 \\
& Sig. & .000 \\
\hline Source: Primary Data is Processed
\end{tabular}

After extraction process, the results of re-testing can be seen from the table above, and has increased from 0.824 to 0.829 with a fixed significance $(0.000)$. Likewise with the antimatrix table image in the Anti Image Correlation section, it shows the MSA value of the remaining variables that have MSA values above that they can be analyzed further

Table 4. Communalities

\begin{tabular}{lcc}
\hline & Initial & Extraction \\
\hline X2.1 & 1.000 & .808 \\
X2.2 & 1.000 & .821 \\
X3.1 & 1.000 & .902 \\
X3.2 & 1.000 & .685 \\
X3.3 & 1.000 & .837 \\
X3.4 & 1.000 & .858 \\
X4.1 & 1.000 & .767 \\
X4.2 & 1.000 & .655 \\
X4.3 & 1.000 & .679 \\
X5.1 & 1.000 & .915 \\
X5.2 & 1.000 & .622 \\
X6.1 & 1.000 & .627 \\
X6.2 & 1.000 & .867 \\
X7.3 & 1.000 & .721 \\
X7.4 & 1.000 & .680 \\
\hline Extraction Method: Principal Component Analysis.
\end{tabular}

Based on table 4 above the value of communalities all variables have values above 0.5 , so variables can be further analyzed. 
Table 5 Total Variance Explained

\begin{tabular}{|c|c|c|c|c|c|c|c|c|c|}
\hline \multirow{2}{*}{ Component } & \multicolumn{3}{|c|}{ Initial Eigenvalues } & \multicolumn{3}{|c|}{$\begin{array}{l}\text { Extraction Sums of Squared } \\
\text { Loadings }\end{array}$} & \multicolumn{3}{|c|}{$\begin{array}{c}\text { Rotation Sums of Squared } \\
\text { Loadings }\end{array}$} \\
\hline & Total & $\begin{array}{c}\% \text { of } \\
\text { Variance }\end{array}$ & $\underset{\%}{\text { Cumulative }}$ & Total & $\begin{array}{c}\% \text { of } \\
\text { Variance }\end{array}$ & $\underset{\%}{\text { Cumulative }}$ & Total & $\begin{array}{c}\% \text { of } \\
\text { Variance }\end{array}$ & $\begin{array}{c}\text { Cumulative } \\
\%\end{array}$ \\
\hline 1 & 6.549 & 43.657 & 43.657 & 6.549 & 43.657 & 43.657 & 4.549 & 30.329 & 30.329 \\
\hline 2 & 2.264 & 15.094 & 58.751 & 2.264 & 15.094 & 58.751 & 3.373 & 22.484 & 52.813 \\
\hline 3 & 1.546 & 10.307 & 69.058 & 1.546 & 10.307 & 69.058 & 1.815 & 12.101 & 64.914 \\
\hline 4 & 1.085 & 7.231 & 76.289 & 1.085 & 7.231 & 76.289 & 1.706 & 11.376 & 76.289 \\
\hline 5 & .663 & 4.419 & 80.709 & & & & & & \\
\hline 6 & .578 & 3.855 & 84.564 & & & & & & \\
\hline 7 & .533 & 3.553 & 88.116 & & & & & & \\
\hline 8 & .427 & 2.849 & 90.965 & & & & & & \\
\hline 9 & .382 & 2.547 & 93.512 & & & & & & \\
\hline 10 & .310 & 2.067 & 95.579 & & & & & & \\
\hline 11 & .213 & 1.421 & 97.000 & & & & & & \\
\hline 12 & .179 & 1.192 & 98.192 & & & & & & \\
\hline 13 & .149 & .992 & 99.184 & & & & & & \\
\hline 14 & .081 & .539 & 99.723 & & & & & & \\
\hline 15 & .042 & .277 & 100.000 & & & & & & \\
\hline
\end{tabular}

Extraction Method: Principal Component Analysis.

Based on table 5 above, it can be seen that there are 15 variables (components) that are included in the factor analysis, namely the belief that the seller has a good reputation (X2.1), guarantee of security and confidentiality (X2.2), structuring neat features and easy to understand (X3.1), information provided is complete and accurate (X3.2), responding to buyers requests accurately and quickly (X3.3), establishing good relationships with buyers (X3 . 4), Flexible use (X4. 1), Energy saving (X4.2), Time Efficiency (X4.3), Reference group (X5.1), Family (X5.2), Advertisements (X6.1), Discounts / Discounts (X6.2) , Reuse (X7.3), Experience (X7.4). In the table, only 4 factors are formed, because with one number factor the eigen value is still above 1, with two eigen value factors still above 1, with three number factors still above 1 , four are still above one factors, five factors are below 1 Therefore, only 4 factors are limited.

Table 6. Componen Matrix (a)

\begin{tabular}{|c|c|c|c|c|}
\hline & \multicolumn{4}{|c|}{ Component } \\
\hline & 1 & 2 & 3 & 4 \\
\hline X5.1 & .930 & -.032 & .219 & -.029 \\
\hline X6.2 & .896 & -.016 & .233 & -.098 \\
\hline $\mathrm{X} 2.1$ & .849 & .013 & .294 & .027 \\
\hline $\mathrm{X} 2.2$ & .823 & .028 & .353 & -.138 \\
\hline X3.1 & .820 & -.114 & -.449 & .125 \\
\hline X3.2 & .792 & -.081 & -.186 & .126 \\
\hline $\mathrm{X} 3.4$ & .757 & -.110 & -.502 & .144 \\
\hline X5.2 & .752 & .008 & .230 & -.060 \\
\hline X3.3 & .751 & -.115 & -.489 & .144 \\
\hline X6.1 & .574 & -.350 & .332 & -.255 \\
\hline $\mathrm{X} 4.3$ & .169 & .806 & .019 & .007 \\
\hline $\mathrm{X} 4.1$ & .118 & .678 & -.152 & -.519 \\
\hline X7.3 & .189 & .649 & -.059 & .511 \\
\hline $\mathrm{X} 4.2$ & .251 & .564 & -.307 & -.424 \\
\hline X7.4 & .105 & .496 & .470 & .449 \\
\hline
\end{tabular}


From table 6 above can be seen as follows: Company has a good reputation (X2.1) : The correlation between X2.1 and factor 1 is 0.849 (strong because it is above 0.5 ). The correlation between X2.1 and factor 2 is 0.013 (weak because it is below 0.5). The correlation between X2.1 and factor 3 is 0.294 (weak because it is below 0.5). Correlation between X.2.1 and factor 4 is 0.027 (weak because it is below 0.5). And for the next variable can see the distribution to 15 variables that are spread out in 4 factors.

Table 7. Rotated Component Matrix (a)

\begin{tabular}{llrrr}
\hline & \multicolumn{4}{c}{ Component } \\
\cline { 2 - 5 } X2.2 & 1 & 2 & 3 & \multicolumn{1}{l}{. } \\
X5.1 & .871 & .200 & .114 & .095 \\
X6.2 & .859 & .402 & .053 & .108 \\
X2.1 & .854 & .350 & .099 & .070 \\
X6.1 & .823 & .309 & .019 & .186 \\
X5.2 & .732 & .078 & -.109 & -.272 \\
X3.4 & .730 & .272 & .076 & .097 \\
X3.1 & .276 & .882 & .061 & -.018 \\
X3.3 & .360 & .876 & .064 & -.014 \\
X3.2 & .279 & .870 & .053 & -.019 \\
X4.1 & .489 & .664 & .012 & .069 \\
X4.2 & .044 & -.054 & .870 & .074 \\
X4.3 & .048 & .182 & .786 & .039 \\
X7.3 & .055 & -.011 & .592 & .571 \\
X7.4 & -.067 & .222 & .186 & .795 \\
\hline & .205 & -.212 & -.038 & .769 \\
\hline
\end{tabular}

Extraction Method: Principal Component Analysis.

Rotation Method: Varimax with Kaiser Normalization.

a. Rotation converged in 6 iterations.

Based on table 7 above the component the rotated component matrix shows a clearer and more obvious distribution of variables. Below this will be explained will go into which factors a variable exists, namely:

Thus, the factors seen from the value of the biggest loading factor which is in which, namely:

Factor 1 consists of: Trust companies have a good reputation, Guarantee security and confidentiality, Reference groups, Family, Advertisements, Discounts / discounts.

Factor 2 consists of: Arrangement of features neat and easy to understand, Information provided is complete and accurate, Responding to buyers' requests accurately and quickly, Establishing good relationships with buyers.

Factor 3 consists of: Use flexible, save energy, time efficiency and Factor 4 consists of: Reuse, Experience.

Table 8. Component Transformation Matrix

\begin{tabular}{ccccc}
\hline Component & 1 & 2 & 3 & 4 \\
\hline 1 & .777 & .609 & .126 & .103 \\
2 & -.106 & 728 & -.270 & .674 \\
3 & .582 & -.128 & .720 & .242 \\
4 & -.217 & .289 & -.627 & .690 \\
\hline
\end{tabular}

Extraction Method: Principal Component Analysis.

Rotation Method: Varimax with Kaiser Normalization. 
Based on table 4.50 above, it can be explained that in the diagonal factor (component) 1 , $2,3,4,(0.777 ; 0.728 ; 0.720 ; 0.690)$. You can see that only four factors have values above 0.5 , which means they have a high correlation.

According to Zaini Hasan in Saputro [9] said giving names and concepts were based on the general meaning of the variables included in it.

Factor 1 is called Psychological and social factors with a total variance of $43.66 \%$, which includes: Trustworthiness and a loading factor of 0.871 . , Reference group by factor loading 0.859, Family Perception with a loading factor of 0.730 , Ads with a loading factor of 0.732 , Discounted prices with a loading factor of 0.854 .

Factor 2 is called the Functional Factor with a total variance of $15.09 \%$, which has several variables which include: Arrangement of neat features and easy to understand loading factor of 0.876 , information is provided and is accurate with a loading factor of 0.664 , Responding to the buyer with a fast loading factor of 0.870 , establishing good relationships with buyers with a loading factor of 0.882 .

Factor 3 is called the Ease Factor with a total variance of $10.31 \%$, with a loading factor of 0.870 , Energy saving with a loading factor of 0.786 , Time efficiency with a loading factor of 0.592 .

Factor 4 is called Personal Factor with a total variance of $7.23 \%$, Reuse with a loading factor of 0.795 , Experience with a loading factor of 0.769 .

\section{Conclusion and Recomendations}

\section{a. Conclusion}

Based on the results of an overall analysis of factors that determine the decision to purchase products online at FEB University students, Dr. Soetomo Surabaya which consists of psychological and social factors, functional factors, convenience factors and personal factors. Where psychological factors have a total variance value of $43.66 \%$, functional factors have a total variance value of $15.09 \%$, convenience factors have a total variance value of $10.31 \%$ and personal factors have a total variance value of $7.23 \%$. The most important factors determining the decision to purchase products online at FEB University students Dr. Soetomo Surabaya is a Psychological and social factor which has the largest total variance value of $43.66 \%$.

\section{b. Suggestion}

From the results of research and based on the conclusions that are available, there are things that follow: For Companies :Given that 4 factors influence consumers towards purchasing products online, the producers need to pay attention to matters relating to the four factors, namely psychological and social factors, functional factors, convenience factors, and personal influence factors consumers in purchasing products online. The four factors come from inside and outside of the consumer.

Relates to the most important or dominant factors that determine the decision to purchase products online. In this study, the producers need to pay attention to things that are related to consumer psychological factors that influence purchasing decisions.

For Consumers : In purchasing products online, consumers should first look at feedback given by other consumers to online companies, companies that have feedback or comments that are good compared to buying companies that have poor feedback or comments. and negative. So that it can minimize fraud that occurs in online purchases. 


\section{Reference}

[1] P. Kotler and K. L. Keller, Manajemen Pemasaran, Jilid 1 Edisi Kedua Belas, Terjemahan Bob Sabran. Jakarta: Indeks, 2007.

[2] F. Tjiptono and G. Chandra, Pemasaran Strategik Edisi 2, 2nd ed. Yogyakarta: Andi, 2012.

[3] M. Suyanto, E-commerce Perusahaan Top Duni. Yogyakarta: Andi, 2003.

[4] P. Kotler, Manajemen Pemasaran. Edisi 13. Jakarta: Erlangga, 2009.

[5] E. Contantinides, "Inflluencing the online consumer's behaviour," J. Internet Res., vol. 14, no. 2, 2004.

[6] Sugiyono, Metode Penelitian Kuantitatif Kualitatif dan R\&D. Bandung: Alfabeta, 2008.

[7] J. Sarwono, Metode Penelitian Kuantitatif dan Kualitatif. Jogjakarta: Graha Ilmu, 2011.

[8] R. A. Jhnson and D. W. Wichern, Applied Multivariate Statistical Analysis 5th. New Jersey: Prentice Hall Inc., 2002.

[9] F. S Saputro, "Analisis Faktor-Faktor Yang Mempengruhi Konsumen Dalam Memilih Warnet (Clik Net) di Ciputat," J. Manaj. UIN, 2007. 